\title{
Meal frequency and plasma lipids and lipoproteins
}

\author{
BY JIM MANN \\ University of Otago, PO Box 56, Dunedin, New Zealand
}

\begin{abstract}
Epidemiological data suggesting benefits of increased meal frequency on CHD risk and lipid and lipoprotein levels may be flawed because of biases associated with the method of data collection. In normolipidaemic individuals increasing meal frequency from three to six or more meals daily over a period of several weeks appears to be associated with reduced levels of total and LDL-cholesterol, possibly due to reduced cholesterol synthesis or enhancement of reverse cholesterol transport. However, in non-obese individuals with polygenic hyperlipidaemia and non-insulin-dependent diabetes, altered meal frequency does not appear to confer similar benefits. The reasons for the different responses in these groups of subjects is not clear. The reported effects of altered meal frequency on diurnal levels of triacylglycerols and fatty acids are more variable, with benefits being reported principally in association with meal frequencies exceeding those which might be translated into practical recommendations. Present data preclude recommendations concerning meal frequency on the basis of effects on lipids and lipoproteins. Even in healthy individuals amongst whom benefits have been observed, the periods of observation have been relatively short and it is not known whether adaptation occurs. Further research should focus on longer-term studies in healthy individuals as well as hyperinsulinaemic and diabetic subjects. For those individuals choosing to have a large number of small meals each day, it is relevant to emphasize that no untoward effects of increased meal frequency on lipids or lipoproteins have been demonstrated.
\end{abstract}

Meal frequency: Lipids: Lipoproteins: Plasma

The suggestion that meal frequency might alter lipid levels in human subjects is not new. More than 30 years ago Gwinup et al. (1963) compared the effects of 'nibbling' and 'gorging' on serum lipids. The higher lipid levels observed on the 'gorging' diet were considered to be the explanation for the observation also made many years ago that reduced meal frequency or 'gorging' (i.e. one or two meals daily) was associated with an increased risk of cardiovascular disease (Fabry et al. 1968). The evidence for the protective effect of increased meal frequency against CHD is weak since it is based on cross-sectional epidemiological studies which are subject to a considerable degree of bias (Fabry et al. 1968). The present review considers the appreciable number of studies undertaken subsequently to address various aspects of the relationship between meal frequency and plasma lipids. In particular, the potentially-different effects in healthy normolipidaemic individuals, people with polygenic hyperlipidaemia and those with diabetes are considered. Practical recommendations, if they are to be made at all, require clear evidence of long-term benefit in free-living individuals.

\section{STUDIES IN HEALTHY NORMOLIPIDAEMIC INDIVIDUALS}

Two epidemiological studies have indicated that frequency of eating is inversely related to hypercholesterolaemia (Fabry et al. 1964; Edelstein et al. 1992). For example, Edelstein et al. (1992) related meal frequency to plasma lipids in 2034 white men and women aged 50 81 years in the USA. They found age-adjusted total and (LDL)-cholesterol to be appreciably lower $(0.23$ and $0.16 \mathrm{mmol} / 1$ respectively) amongst those who reported eating four meals or more daily, compared with those reporting one to two meals daily. The association persisted after adjustment for smoking, alcohol, waist : hip ratio, systolic blood 
Table 1. Studies of changing meal frequency in normolipidaemic individuals on fasting lipids and lipoproteins

\begin{tabular}{|c|c|c|c|c|}
\hline Reference & Subjects & Background diet* & $\begin{array}{l}\text { Meal frequency and } \\
\text { duration of study }\end{array}$ & Results \\
\hline $\begin{array}{l}\text { Gwinup et al. } \\
\text { (1963) }\end{array}$ & $\begin{array}{l}\text { Two patients with } \\
\text { slightly raised li- } \\
\text { pids, three with } \\
\text { normal lipids }\end{array}$ & $\begin{array}{l}\text { Usual foods } \\
44 \% \text { fat } \\
38 \% \text { CHO }\end{array}$ & $\begin{array}{l}\text { One } v \text {. three } v . \text { ten } \\
\text { meals } / \mathrm{d}, 14 \mathrm{~d} \text { or } \\
\text { longer on each diet }\end{array}$ & $\begin{array}{l}\text { Decrease in lipid } \\
\text { levels when chang- } \\
\text { ing from three to } \\
\text { ten meals/d } \\
\text { Increase in levels } \\
\text { when changing } \\
\text { from three to one } \\
\text { meals/d }\end{array}$ \\
\hline Cohn (1964) & $\begin{array}{l}\text { Five men, one } \\
\text { woman, initial } \\
\text { total cholesterol } \\
5.7 \mathrm{mmol} / \mathrm{l}\end{array}$ & $\begin{array}{l}\text { Usual diet (macro- } \\
\text { nutrient content not } \\
\text { reported }\end{array}$ & $\begin{array}{l}\text { Three meals } / \mathrm{d} \text { for } 2 \\
\text { weeks, six meals } / \mathrm{d} \\
\text { for } 4 \text { weeks }\end{array}$ & $\begin{array}{l}\text { Lower serum choles- } \\
\text { terol on six meals } / \mathrm{d} \\
\text { after } 2 \text { weeks, but } \\
\text { reversion to initial } \\
\text { levels after } 4 \text { weeks }\end{array}$ \\
\hline $\begin{array}{l}\text { Nunes \& Canham } \\
\quad(1963)\end{array}$ & $\begin{array}{l}\text { Eleven men, initial } \\
\text { cholesterol not re- } \\
\text { ported }\end{array}$ & Details not provided & $\begin{array}{l}\text { Two } v \text {. nine meals/d, } \\
6 \text { weeks on each } \\
\text { diet, crossover de- } \\
\text { sign }\end{array}$ & $\begin{array}{l}\text { Significant change in } \\
\text { cholesterol from } \\
\text { control period, but } \\
\text { not sustained }\end{array}$ \\
\hline Bortz et al. (1966) & $\begin{array}{l}\text { Six obese women } \\
19-56 \text { years, initial } \\
\text { total cholesterol } \\
5.3 \mathrm{mmol} / 1\end{array}$ & $\begin{array}{l}\text { Restricted-energy } \\
\text { liquid formula } \\
\text { diet }(2500 \mathrm{~kJ} / \mathrm{d}) \\
38 \% \text { fat, } 53 \% \\
\text { CHO or } 6 \% \text { fat, } \\
45 \% \text { CHO }\end{array}$ & $\begin{array}{l}\text { One } v \text {. three } v \text {. nine } \\
\text { meals } / \mathrm{d} \\
\text { Approximately } 20 \mathrm{~d} \\
\text { on each diet }\end{array}$ & $\begin{array}{l}\text { Reduction in choles- } \\
\text { terol and triacyl- } \\
\text { glycerol associated } \\
\text { with weight loss, } \\
\text { independent of } \\
\text { meal frequency }\end{array}$ \\
\hline $\begin{array}{l}\text { Irwin \& Feeley } \\
\text { (1967) }\end{array}$ & $\begin{array}{c}\text { Fifteen women, 17-21 } \\
\text { years, initial cho- } \\
\text { lesterol } 4.4 \mathrm{mmol} / 1\end{array}$ & $38 \%$ fat, $55 \%$ CHO & $\begin{array}{c}\text { Three equal meals/d } \\
v . \text { two small and } \\
\text { one large meal/d } v \text {. } \\
\text { six equal meals } / \mathrm{d} \text {, } \\
20 \mathrm{~d} \text { on each }\end{array}$ & $\begin{array}{l}\text { Lower cholesterol on } \\
\text { three equal meals/d } \\
\text { cf. other diets, but } \\
\text { general increase in } \\
\text { cholesterol over } \\
\text { study period }\end{array}$ \\
\hline $\begin{array}{l}\text { Young et al. } \\
\quad(1972)\end{array}$ & $\begin{array}{l}\text { Ten men, } 21-27 \\
\text { years, initial total } \\
\text { cholesterol } 5 \cdot 5 \\
\text { mmol } / 1\end{array}$ & $\begin{array}{l}38 \% \text { fat, } 44 \% \mathrm{CHO} \\
\text { cholesterol } 855 \mathrm{mg}\end{array}$ & $\begin{array}{l}\text { One } v \text {. six meals } / \mathrm{d}, 5 \\
\text { weeks on each diet, } \\
\text { randomized cross- } \\
\text { over }\end{array}$ & $\begin{array}{l}\text { Cholesterol } 8.7 \% \\
\text { higher on one meal } \\
\text { cf. six meals } / \mathrm{d}\end{array}$ \\
\hline $\begin{array}{l}\text { Wadhwa et al. } \\
\text { (1973) }\end{array}$ & $\begin{array}{l}\text { Thirteen men, } 20-30 \\
\text { years, total choles- } \\
\text { terol } 5 \cdot 1-5.4 \\
\text { mmol } / 1\end{array}$ & $\begin{array}{l}40 \% \text { fat (maize oil or } \\
\text { butter oil) } 47 \% \\
\text { CHO }\end{array}$ & $\begin{array}{l}\text { Two } v \text {. eight meals/d, } \\
4 \text { weeks on each } \\
\text { diet, randomized } \\
\text { sequence }\end{array}$ & $\begin{array}{l}\text { No significant differ- } \\
\text { ences on the two } \\
\text { diets }\end{array}$ \\
\hline $\begin{array}{l}\text { Peters et al. } \\
\quad(1979)\end{array}$ & $\begin{array}{l}\text { Eight healthy men } \\
20-30 \text { years, total } \\
\text { cholesterol } 5 \cdot 4-5 \cdot 5 \\
\text { mmol/1 }\end{array}$ & Usual fat and $\mathrm{CHO}$ & $\begin{array}{l}\text { Three } v \text {. eight } \\
\text { meals/d, } 2 \text { weeks } \\
\text { on each diet, ran- } \\
\text { domized crossover }\end{array}$ & $\begin{array}{l}\text { No significant differ- } \\
\text { ences on the two } \\
\text { diets }\end{array}$ \\
\hline $\begin{array}{l}\text { Jenkins et al. } \\
\text { (1989) }\end{array}$ & $\begin{array}{l}\text { Seven men, } 31-51 \\
\text { years, initial cho- } \\
\text { lesterol } 5 \cdot 1-5 \cdot 3 \\
\text { mmol } / 1\end{array}$ & $33 \%$ fat, $52 \%$ CHO & $\begin{array}{l}\text { Three } v \text {. seventeen } \\
\text { meals } / \mathrm{d}, 2 \text { weeks } \\
\text { on each, crossover } \\
\text { design }\end{array}$ & $\begin{array}{l}\text { Reduction of total } \\
\text { cholesterol }(8.5 \%) \text {, } \\
\text { LDL-cholesterol } \\
(13.5 \%) \text { and apo B } \\
(15.1 \%) \text { on seven- } \\
\text { teen } v . \text { three meals }\end{array}$ \\
\hline $\begin{array}{l}\text { Arnold et al. } \\
\quad \text { (1993) }\end{array}$ & $\begin{array}{l}\text { Nineteen subjects, } \\
\text { mean age } 32 \text { years, } \\
\text { mean initial cho- } \\
\text { lesterol } 4.49 \\
\text { mmol/ } 1\end{array}$ & $30 \%$ fat, $54 \%$ CHO & $\begin{array}{l}\text { Three } v \text {. nine meals/d, } \\
2 \text { weeks on each } \\
\text { period, randomized } \\
\text { crossover design }\end{array}$ & $\begin{array}{l}\text { Reduction of total } \\
\text { cholesterol }(6.5 \%) \text {, } \\
\text { LDL-cholesterol } \\
(8.1 \%) \text {, and HDL- } \\
\text { cholesterol }(4.1 \%) \\
\text { on nine } v . \text { three } \\
\text { meals }\end{array}$ \\
\hline
\end{tabular}


Table 1. continued

\begin{tabular}{|c|c|c|c|c|}
\hline Reference & Subjects & Background diet* & $\begin{array}{l}\text { Meal frequency and } \\
\text { duration of study }\end{array}$ & Results \\
\hline $\begin{array}{l}\text { McGrath \& } \\
\text { Gibney (1994) }\end{array}$ & $\begin{array}{l}\text { Twelve men with } \\
\text { mean eating fre- } \\
\text { quency } 6.0 \text { times } \\
\text { daily; eleven with a } \\
\text { frequency of } 3.1 \\
\text { daily, mean age of } \\
\text { groups } 29 \text { and } 30 \\
\text { years, mean initial } \\
\text { cholesterol } 4.8 \text { and } \\
5.0 \text { mmol } / 1\end{array}$ & $\begin{array}{l}39 \% \text { fat, } 41-44 \% \\
\text { CHO }\end{array}$ & $\begin{array}{l}\text { Those eating six times } \\
\text { daily changed to } \\
\text { three, those on } \\
\text { three meals daily } \\
\text { increased to six }\end{array}$ & $\begin{array}{l}\text { Increasing from three } \\
\text { to six meals asso- } \\
\text { ciated with signifi- } \\
\text { cant reduction in } \\
\text { total and LDL- } \\
\text { cholesterol }\end{array}$ \\
\hline
\end{tabular}

CHO, carbohydrate.

*Values represent \% energy from fat and $\mathrm{CHO}$.

pressure, BMI and dietary nutrients. However, these findings must be interpreted with caution since they are derived from cross-sectional data.

The investigations which have included healthy normolipidaemic individuals and which have directly compared the effects of diets which have differed in meal frequency on fasting lipids and lipoproteins are summarized in Table 1, which includes only those studies in which the experimental diets were each followed continuously for at least 2 weeks or more. One early study (Bortz et al. 1966) is difficult to interpret because of associated weight reduction, and another (Irwin \& Feeley, 1967) by the fact that cholesterol levels increased over the entire study period. However, the overall trend (seven of the remaining nine studies) is towards reduced levels of total and LDL-cholesterol when diets comprising six or more meals daily were compared with diets consisting of three or fewer meals each day. Furthermore, the studies showing no differences in lipid levels between diets differing in meal frequency involved small numbers of individuals and the CI (not calculated by the authors) would have included the percentage differences found in the 'positive' studies.

Formal meta-analyses would be inappropriate because of the considerable variation in study design, in particular the varying macronutrient composition of the background diets, the wide range of meal frequencies compared, the variability of energy intake and the fact that some studies involved the use of formula diets, others preportioned food and some, free-living individuals preparing their own foods under the direction of the researchers. The three most recent studies warrant further comment. Two involved the use of a randomized cross-over design and careful dietary supervision to ensure that total energy intake and macronutrient distribution were comparable on the two experimental diets. While the results of both studies show fairly convincing improvements in lipoprotein profile (particularly with regard to total and LDL-cholesterol) it must be appreciated that both have limitations when attempting to extrapolate the results into practical recommendations. The study by Jenkins et al. (1989) involved seven men consuming three meals daily or seventeen snacks daily (the nibbling diet), the latter clearly being impractical for translation into recommendations for the public at large. The study by Arnold et al. (1993) involved a more feasible comparison (three $v$. nine meals) but both studies were of limited duration ( 2 and 4 weeks respectively). Adaptation to dietary change is a well-recognized phenomenon and there is no clear evidence, one way or another, whether adaption might occur in this context. Indeed, one very early study (Cohn, 1964), albeit small and of inadequate design, suggested that this might be the case. 
McGrath \& Gibney (1994) adopted a different approach. They identified men who habitually adopted 'snacking' (meal frequency six times daily) and 'non-snacking' (meal frequency three times daily) patterns and persuaded them to convert to the alternative eating pattern. Increasing meal frequency was accompanied by a significant reduction in total and LDL-cholesterol. The findings in the group which decreased meal frequency were explained by the changes in nutrient intake; an increase in percentage energy from protein, fat, saturated fatty acids and alcohol.

The encouragement towards further research in this field should come from the potential benefit in terms of reducing cardiovascular risk. The order of magnitude of risk reduction which might be expected with the degree of lowering of total and LDLcholesterol demonstrated in the study of free-living individuals by Arnold et al. (1993) is considerable. Furthermore, there is now fairly good evidence concerning a mechanism by which increased meal frequency might reduce total and LDL-cholesterol. Insulin has a key role in enhancing the hepatic synthesis of cholesterol through its ability to stimulate hydroxymethyglutaryl-CoA (HMGCoA) reductase $(E C$ 1.1.1.88), the rate-limiting step in hepatic cholesterol synthesis (Dietschy \& Brown, 1974). Jenkins et al. (1989) clearly demonstrated decreased mean diurnal insulin levels and reduced $24 \mathrm{~h}$ urinary C-peptide output on the nibbling as compared with the three-meal diet. A more recent study (Jones et al. 1993), admittedly of very short duration ( $3 \mathrm{~d}$ on each diet comparing six and three meals daily), demonstrated reduced cholesterol synthesis (measured by ${ }^{2} \mathrm{H}$ incorporation into plasma free cholesterol using constrained and unconstrained curve fit models) as well as reduced insulin and gastric inhibitory polypeptide (GIP) concentrations on the six-meal formula diet. An alternative explanation involves reverse cholesterol transport. Removal of cholesterol via this route occurs only in the postprandial phase, even after only small amounts of fat are ingested and, therefore, may be facilitated when meal frequency is increased (Flaherty \& Gibney, 1994).

There is much less evidence concerning the effect of meal frequency on other indicators of lipid metabolism and cardiovascular risk and the data which do exist suggest inconsistent results. Arnold et al. (1993) found a very small and marginally-significant reduction in HDL-cholesterol on three $v$. nine meals daily, a finding not confirmed by Jenkins et al. (1989). There is no consistent evidence for differences in fasting triacylglycerol or free fatty acid levels with varying meal frequency. Some investigators (Bortz et al. 1969; Wadhwa et al. 1973; Jenkins et al. 1992) have suggested differences in triacylglycerol and free fatty acid levels during the day with altered meal frequency, but in well-conducted studies it appears that meal-related fluctuations, even with extreme variation in meal frequency, are modest or negligible (Schlierf \& Dorrow, 1973; van Gent et al. 1979; Jenkins et al. 1989; Wolever et al. 1990). A very recent study of eleven young women has compared the effects of twelve and three meals daily on postprandial triacylglycerol, non-esterified fatty acids, glucose, insulin, gastric inhibitory polypeptide, glucagon-like peptide- 1 levels as well as fasting lipids and lipoproteins and post-heparin lipoprotein lipase (EC 3.1.1.34) activity after 2 weeks on each diet. The only significant difference between the two diets was a small but significant increase in HDL-cholesterol in subjects following the 'gorging' as compared with the 'nibbling diet' (Murphy et al. 1996).

\section{STUDIES IN HYPERLIPIDAEMIC INDIVIDUALS}

Gwinup et al. (1963) in their original study included two patients with slightly elevated lipid levels, but only three studies, summarized in Table 2, have examined the effects of meal frequency in hyperlipidaemic individuals. Young et al. (1971) studied eleven men 
aged 20-25 years all of whom were obese and on weight-reducing diets. Their cholesterol levels were initially in the range $7-8 \mathrm{mmol} / 1$. Eating one meal daily was associated with higher levels of cholesterol in comparison with regimens involving three or six meals daily, but there were no differences between the three and six-meal diets. Jordan \& Novascone (1989) studied seventeen men aged 43-68 years with fasting cholesterol levels greater than $6.2 \mathrm{mmol} / \mathrm{l}$. Three or six meals daily were compared using a cross-over design, with each diet period of 6 weeks duration. Throughout the study participants followed a self-selected, 'heart healthy', modified-fat diet. There were no significant differences in fasting total, LDL-, HDL-cholesterol or triacylglycerol. Arnold et al. (1994) compared three and nine meals daily (also using a cross-over design) in sixteen men and women with cholesterol levels ranging from 5.9 to $7.7 \mathrm{mmol} / 1$ (mean $6.8 \mathrm{mmol} / \mathrm{l}$ ). During the 4-week periods on each diet there were no significant differences in fasting concentrations of plasma total, LDL- and HDL-cholesterol, apolipoprotein A-1 and B or in urinary C-peptide. Plasma triacylglycerol and serum insulin responses to a high-fat meal $(55 \mathrm{~g}$ fat, $19 \mathrm{~g}$ protein and $90 \mathrm{~g}$ carbohydrate) on the two diets were similar.

Thus, while the data are limited it seems that there is at present no evidence to suggest that non-obese individuals with moderately elevated lipid levels will benefit from increased meal frequency. It is of interest to speculate why hyperlipidaemic and normolipidaemic individuals might differ in this respect and, in particular, to contrast the two New Zealand studies from the same research group (Arnold et al. 1993, 1994). The hyperlipidaemic

Table 2. Studies of changing meal frequencies on fasting lipids and lipoproteins in hyperlipidaemic individuals

\begin{tabular}{|c|c|c|c|c|}
\hline Reference & Subjects & Background diet* & $\begin{array}{l}\text { Meal frequency and } \\
\text { duration of study }\end{array}$ & Results \\
\hline Young et al. (1971) & $\begin{array}{l}\text { Eleven obese men } \\
20-25 \text { years, } \\
\text { cholesterol levels } \\
7-8 \mathrm{mmol} / 1\end{array}$ & $\begin{array}{l}\text { Restricted energy, } \\
51 \% \text { fat, } 22 \% \\
\text { CHO }\end{array}$ & $\begin{array}{l}\text { Baseline, three } \\
\text { meals/d for } 16 \mathrm{~d} \text {. } \\
\text { then two of three } \\
\text { regimens: one, } \\
\text { three or six } \\
\text { meals/d, } 5 \text { weeks } \\
\text { on each diet }\end{array}$ & $\begin{array}{l}\text { Significantly higher } \\
\text { cholesterol on one } \\
\text { meal/d cf. three or } \\
\text { six meals/d }\end{array}$ \\
\hline $\begin{array}{l}\text { Jordan \& Novascone } \\
\quad \text { (1989) }\end{array}$ & $\begin{array}{l}\text { Seventeen men, } 43- \\
68 \text { years, choles- } \\
\text { terol level greater } \\
\text { than } 6.2 \mathrm{mmol} / 1 \text { at } \\
\text { recruitment }\end{array}$ & $\begin{array}{l}\text { Self-selected, } 33 \% \\
\text { fat }\end{array}$ & $\begin{array}{l}\text { Three } v \text {. six meals } / d \text {, } \\
6 \text { weeks on each } \\
\text { diet, crossover de- } \\
\text { sign }\end{array}$ & $\begin{array}{l}\text { No significant differ- } \\
\text { ences in fasting } \\
\text { total, LDL-, HDL- } \\
\text { cholesterol or tri- } \\
\text { acylglycerol }\end{array}$ \\
\hline Amold et al. (1994) & $\begin{array}{l}\text { Sixteen men and } \\
\text { women, } 34-66 \\
\text { years, average } \\
\text { cholesterol } 6.8 \\
\text { mmol } / 1\end{array}$ & $\begin{array}{c}\text { Self selected, } 34 \% \\
\text { fat, } 49 \% \mathrm{CHO}\end{array}$ & $\begin{array}{l}\text { Three } v \text {. nine } \\
\text { meals } / \mathrm{d}, 4 \text { weeks } \\
\text { on each diet, } \\
\text { crossover design }\end{array}$ & $\begin{array}{l}\text { No significant differ- } \\
\text { ences in fasting } \\
\text { total, LDL-, HDL- } \\
\text { cholesterol, tria- } \\
\text { cylglycerol apoli- } \\
\text { poprotein A-1 and } \\
\text { B; no variation in } \\
\text { response of plasma } \\
\text { triacylglycerol or } \\
\text { insulin to high-fat } \\
\text { meal on two diets; } \\
\text { similar } 24 \text { h urin- } \\
\text { ary C-peptide }\end{array}$ \\
\hline
\end{tabular}


group consumed a significantly greater percentage of their total energy as fat (mean $34 \%$ compared with $30 \%$ ) and less as carbohydrate (mean $49 \%$ compared with $54 \%$ ) or simple sugars. This may be significant as it has been suggested that the composition of the background diet, particularly the carbohydrate content, may influence the metabolic response to an altered periodicity of nutrient intake (Fabry \& Braun, 1976; Adams \& Morgan, 1981).

Differences in metabolism in normolipidaemic and hyperlipidaemic individuals may also be relevant. If the changes in LDL-cholesterol in normolipidaemic individuals are due to alteration in insulin and its effect on HMGCoA reductase activity or to altered reverse cholesterol transport, a difference in these mechanisms in hyperlipidaemic individuals might explain why their total and LDL-cholesterol levels did not change. Measures of insulin secretion and insulin levels in the Arnold et al. (1993) study were insufficiently sensitive to be able to comment with certainty that insulin secretion was identical on the three and nine meal regimens.

There is clearly a need for further research concerning the effects of meal frequency on lipid levels in hypercholesterolaemic individuals, but for the present, dietary recommendations aimed at lowering total and LDL-cholesterol should continue to focus on the nature of dietary fat which remains the most important nutritional determinant of this important risk indicator for $\mathrm{CHD}$.

\section{STUDIES IN PEOPLE WITH DIABETES}

Given the potential benefit of impaired glycaemic control and cardiovascular risk profile with altered meal frequency in people with diabetes, it is surprising that virtually no information is available concerning the long-term effects on lipid profiles.

Jenkins et al. (1992) compared three meals and thirteen meals daily in eleven patients with non-insulin-dependent diabetes in the context of a diet which provided $31 \%$ energy from fat and $53 \%$ from carbohydrate. Average triacylglycerol levels were lower over the $9.5 \mathrm{~h}$ study period on thirteen meals, but there was no change in free fatty acids. However, the study involved only $1 \mathrm{~d}$ on each of the regimens. Bertelsen et al. (1993) compared two and six meals in another study involving single-day comparisons and found lower free fatty acids levels (as well as lower glucose and insulin responses) when subjects ate six small meals. Segura et al. (1995) have extended this approach by comparing the effects of three, six, nine, and twelve meals fed over a $12 \mathrm{~h}$ period. Mean day-long concentration of plasma glucose was similar on the four different regimens, but incremental area under the glucose response curve over the whole day was inversely related to the number of meals. Mean day-long plasma insulin concentration for six meals was less than that for three meals, with no further reduction for twelve meals. Non-esterified fatty acids, triacylglycerols and glycerol responses were similar for the four treatments. A different approach was taken by Wolever et al. (1995). They studied the effect of spreading nutrient intake throughout the day on lipid levels in several hundred people with non-insulin-dependent diabetes. They found that spreading total energy and fat intake throughout the day was associated with a reduction in cholesterol levels and suggested that this rather than the number of meals might explain the effect of meal frequency observed in other studies.

As far as I am aware only one study has studied people with diabetes over a longer period. In a randomized investigation we studied thirteen people with non-insulindependent diabetes or persistently-impaired glucose tolerance, who each completed two 4week experimental periods in which three or nine meals daily were eaten in the context of a diet in which fat provided $32 \%$ total energy and carbohydrate 48-51\% total energy on both experimental diets (L. Arnold, M. Ball and J. Mann, unpublished results). Fasting 
Table 3. Fasting lipids and lipoproteins in diabetic subjects consuming three and nine meals daily

(Mean values and standard deviations)

\begin{tabular}{|c|c|c|c|c|c|c|}
\hline \multirow[t]{2}{*}{ Meal frequency... } & \multicolumn{2}{|c|}{ Baseline } & \multicolumn{2}{|c|}{ Three meals/d } & \multicolumn{2}{|c|}{ Nine meals/d } \\
\hline & Mean & SD & Mean & $\mathrm{SD}$ & Mean & SD \\
\hline Total cholesterol (mmol/l) & 5.68 & 1.22 & 5.88 & 1.14 & $5 \cdot 88$ & $1 \cdot 16$ \\
\hline LDL-cholesterol (mmol/l) & 3.65 & 0.92 & 3.98 & 0.94 & 4.03 & 0.94 \\
\hline HDL-cholesterol (mmol/l) & $1 \cdot 10$ & 0.29 & 1.09 & 0.13 & 1.05 & 0.13 \\
\hline Total : HDL-cholesterol & 5.42 & 1.84 & 5.50 & 1.42 & 5.73 & 1.28 \\
\hline Triacylglycerol (mmol/l) & 2.15 & 1.02 & 1.86 & 0.72 & 1.85 & 0.77 \\
\hline Apolipoprotein B (mg/l) & 775 & 251 & 865 & 72 & 905 & 192 \\
\hline
\end{tabular}

lipid, lipoprotein and apoprotein levels were virtually identical on the three and nine meals diets (Table 3 ), as were $24 \mathrm{~h}$ urinary C-peptide values and C-peptide : creatinine, measures of glycaemic control and various metabolic responses to a glucose load. Thus, in people with non-insulin-dependent diabetes, as in hyperlipidaemic individuals, there is to date no evidence of long-term benefit of increased meal frequency.

\section{SUMMARY AND CONCLUSIONS}

In healthy normolipidaemic individuals there is evidence based on epidemiological data and dietary studies of variable length and scientific quality that increased meal frequency may be associated with a lipoprotein profile likely to be associated with a reduced risk of cardiovascular disease. Furthermore, there is evidence for plausible mechanisms by which increased meal frequency might reduce levels of total and LDL-cholesterol. However, in non-obese individuals with polygenic hyperlipidaemia and non-insulin-dependent diabetes there is at present no evidence for any change in fasting lipid and lipoprotein profiles with altered meal frequency. There is some evidence of benefit of nibbling regimens in terms of reduced diurnal levels of triacylglycerols and free fatty acids, but the data are derived from very-short-term studies and usually with meal frequencies exceeding those which might be translated into practical recommendations for the general public or patients with hyperlipidaemia or diabetes. Further large-scale, long-term and costly studies would be essential before offering recommendations in terms of meal frequency as a consequence of the effects on lipids and lipoproteins. Nevertheless, it is important to emphasize that, for those individuals choosing to have a large number of small meals each day, there is no evidence for any adverse effects of nibbling on the wide range of indicators of lipid metabolism which have been investigated.

\section{REFERENCES}

Adams, C. E. \& Morgan, K. J. (1981). Periodicity of eating: implications for human food consumption. Nutrition Research 1, 525-550.

Arnold, L. M., Ball, M. J., Duncan, A. W. \& Mann, J. (1993). Effect of isoenergetic intake of three or nine meals on plasma lipoproteins and glucose metabolism. American Journal of Clinical Nutrition 57, 446-451.

Arnold, L., Ball, M. \& Mann, J. (1994). Metabolic effects of alterations in meal frequency in hypercholesterolaemic individuals. Atherosclerosis 108, 167-174.

Bertelsen, J., Christiansen, C., Thomsen, C., Poulsen, P. L., Vestergaard, S., Steinov, A., Rasmussen, L. H., Rasmussen, O. \& Hermansen, K. (1993). Effect of meal frequency on blood glucose, insulin, and free fatty acids in NIDDM subjects. Diabetes Care 16, 4-7.

Bortz, W. M., Howat, P. \& Holmes, W. L. (1969). The effect of feeding frequency on diumal plasma free fatty acids and glucose levels. Metabolism 18, 120-123.

Bortz, W. M., Wroldsen, A., Issekutz, B. \& Rodahl, K. (1966). Weight loss and frequency of feeding. New England Journal of Medicine 274, 376-379. 
Cohn, C. (1964). Feeding patterns and some aspects of cholesterol metabolism. Federation Proceedings 23, 76-81.

Dietschy, J. M. \& Brown, M. S. (1974). Effect of alterations of the specific activity of the intracellular acetyl CoA pool on apparent rates of hepatic cholesterogenesis. Journal of Lipid Research 15, 508-516.

Edelstein, S. L., Barrett-Connor, E. L., Wingard, D. L. \& Cohn, B. A. (1992). Increased meal frequency associated with decreased cholesterol concentrations; Rancho Bernado, CA, 1984-1987. American Journal of Clinical Nutrition 55, 664-669.

Fabry. P. \& Braun, T. (1976). Adaptation to the pattern of food intake: some mechanisms and consequences. Proceedings of the Nutrition Society 26, 144-152.

Fabry, P., Fodor, J., Hejl, Z., Braun, T. \& Zvolankova, K. (1964). The frequency of meals: its relation to overweight, hypercholesterolaemia, and decreased glucose-tolerance. Lancet ii, 614-615.

Fabry, P., Fodor, J., Hej1, Z., Geizerova, H. \& Balcarova, O. (1968). Meal frequency and ischaemic heart disease. Lancet ii, 190-191.

Flaherty, L \& Gibney, M. J. (1994). The effect of very low, moderate and high fat snacks on postprandial reverse cholesterol transport in healthy volunteers. Proceedings of the Nutrition Society 53, 124A.

Gwinup, G., Bryon, R. C., Roush, W. H., Kruger, F. A. \& Hamwi, G. J. (1963). Effect of nibbling versus gorging on serum lipids in man. American Journal of Clinical Nutrition 13, 209-213.

Irwin, M. I. \& Feeley, R. M. (1967). Frequency and size of meals and serum lipids, nitrogen and mineral retention, fat digestibility, and urine thiamine and riboflavin in young women. American Journal of Clinical Nutrition 20, 816-824.

Jenkins, D. J. A., Ocana, A., Jenkins, A. L., Wolever, T. M. S., Vuksan, V., Katzman, L., Hollands, M., Greenberg, G., Corey, P., Patten, R., Wong, G. \& Josse, R. G. (1992). Metabolic advantages of spreading the nutrient load: effects of increased meal frequency in non-insulin-dependent diabetes. American Journal of Clinical Nutrition 55, 461-467.

Jenkins, D. J. A., Wolever, T. M. S., Vuksan, V., Brighenti, F., Cunnane, S. C., Rao, A. V., Jenkins, A. L, Buckley, G., Patten, R., Singer, W., Corey, P. \& Josse, R. G. (1989). Nibbling versus gorging: metabolic advantages of increased meal frequency. New England Journal of Medicine 321, 929-934.

Jones, P. J. H., Leitch, C. A. \& Pederson, R. A. (1993). Meal-frequency effects on plasma hormone concentrations and cholesterol synthesis in humans. American Journal of Clinical Nutrition 57, 868-874.

Jordan, J. A. \& Novascone, M. A. (1989). Effect of altered feeding patterns on serum lipids and lipoproteins in adult males. Journal of Human Nutrition and Dietetics 2, 19-24.

McGrath, S. A. \& Gibney, M. J. (1994). The effects of altered frequency of eating on plasma lipids in free living healthy males on normal self selected diets. European Journal of Clinical Nutrition 48, 402-407.

Murphy, M. C., Chapman, C., Lovegrove, J. A, Isherwood, S. G., Morgan, L. M., Wright, J. W. \& Williams, C. M. (1996). Meal frequency: does it determine postprandial lipaemia? European Journal of Clinical Nutrition 50, 491-497.

Nunes W. T. \& Canham, J. E. (1963). The effect of varied periodicity of eating on serum lipids and carbohydrate tolerance in man. American Journal of Clinical Nutrition, 12, 334.

Peters, J. R., Rhodes, J. \& Owens, D. R. (1979). Metabolic effects of altered meal frequency in man. Hormone Metabolism Research 11, 524-525.

Schlierf, G. \& Dorrow, E. (1973). Diurnal patterns of triglycerides, free fatty acids, blood sugar, and insulin during carbohydrate-induction in man and their modification by nocturnal suppression of lipolysis. Journal of Clinical Investigation 52, 732-740.

Segura, A. G., Josse, R. G. \& Wolever, T. M. S. (1995). Acute metabolic effects of increased meal frequency in Type II diabetes: three vs six, nine, and twelve meals. Diabetes Nutrition and Metabolism 8, 331-338.

van Gent, C. M., Pagano Mirani-Oostdijk, C., van Reine, P. H., Frolich, M., Hessel, L. W. \& Terpstra, J. (1979). Influence of meal frequency on diurnal lipid, glucose and insulin levels in normal subjects on a high fat diet; comparison with data obtained on a high carbohydrate diet. European Journal of Clinical Investigation 9 , $443-446$.

Wadhwa, P. S., Young, E. A., Schmidt, K., Elson, C. E. \& Pringle, D. J. (1973). Metabolic consequences of feeding frequency in man. American Journal of Clinical Nutrition 26, 823-830.

Wolever, T. M. S., Innocente, T. \& Palmason, C. (1990). Effect of calorie distribution and diet glycaemic index on blood HbAlc and lipids in NIDDM. Diabetes 39, $239 \mathrm{~A}$.

Wolever, T. M. S., Josse, R. G., Palmason, C. \& Canadian Universities Multicenter Trial Group (1995). Spreading nutrient intake throughout the day associated with reduced serum cholesterol in 342 patients with type 2 diabetes. Nutrition, Metabolism and Cardiovascular Diseases 5, 31-38.

Young, C. M., Frankel, D. L., Simko, V. \& Lutwak, L. (1971). Frequency of feeding, weight reduction, and nutrient utilisation. Journal of the American Dietetic Association 59, 473-480.

Young, C. M., Hutter, L. F., Scanlan, S. S., Rand, C. E., Lutwak, L. \& Simko, V. (1972). Metabolic effects of meal frequency on normal young men. Joumal of the American Dietetic Association 61, 391-398. 